Original Research Article

\title{
Clinico-Microbiological profile in dacryocystitis: a prospective observational study
}

\author{
Garg R. ${ }^{1}$, Gupta P. ${ }^{2}$, Shakya D.K. ${ }^{3}$, Varandani.$^{4}$, Uchainiya A. ${ }^{5}$ \\ ${ }^{1}$ Dr. Ragini Garg, Resident, ${ }^{2}$ Dr. Prabha Gupta, Senior Resident, ${ }^{3}$ Dr. D.K. Shakya, Professor ${ }^{4}$ Dr. Souryakant Varandani, \\ Resident, ${ }^{5}$ Dr. Akanksha Uchainiya, Resident, all authors are affiliated with Department of Ophthalmology, Gajra Raja \\ Medical College, Gwalior, MP, India.
}

Corresponding Author: Dr. Prabha Gupta, Senior Resident, Department of Ophthalmology, Gajra Raja Medical College, Gwalior. E-mail: drprabhagupta@gmail.com

\begin{abstract}
Introduction: Dacryocystitis is the inflammatory condition of the lacrimal sacwhich occur in acute and chronic form. Chronic dacryocystitis is commonly encountered, accounting for $87.1 \%$ of Epiphorawhich causes social embarrassment due to chronic watering from the eye. Understanding the antibiogram for micro organism causing inflammation of lacrimal sac can be useful in choosing the best antimicrobial. Hence the present study was done to evaluate the clinical profile and antibiogram of acute and chronic dacryocystitis. Method: A prospective observational study was done in patients with acute or chronic dacryocystitis attending ophthalmology OPD. Those fulfilling the eligibility criteria were enrolled in the study. Samples were collected from all the cases and were sent to microbiology lab for gram staining, culture and sensitivity. Result: 100 patients of dacryocystitis were enrolled, chronic dacryocystitis was found common than the acute dacryocystitis, along with a female (middle age group) preponderance. The main presenting symptom was watering $(89 \%)$ followed by discharge $(47 \%)$, swelling $(34 \%)$, pain $(23 \%)$ and tenderness $(23 \%)$. Gram positive organisms (72.86\%) were most commonly isolated. Among the Gram-positive organisms, Staph. aureus (37.14\%) while Pseudomonas among Gram negative were the common isolate. Vancomycin and tobramycin are highly active against all Gram positive, tobramycin, gentamycin, fluoroquinolones and cephalosporins are found to be very active against Gram negative bacteria. Conclusion: The most common bacterial isolate in dacryocystitis, prevailing in this geographical area is Staphylococcus (Gram positive) followed by Pseudomonas, Pneumococcus and Staph epidermidis. Combination of Vancomycin and $3^{\text {rd }}$ generation cephalosporin can be used as empirical therapy when the culture reports are awaited.
\end{abstract}

Keywords: Dacryocystitis, Lacrimal sac, Inflammation, Culture and sensitivity

\section{Introduction}

Dacryocystitis is the inflammatory condition of the lacrimal sac [1] which occur in two forms, acute and chronic [2]. Chronic dacryocystitis is commonly encountered, accounting for $87.1 \%$ of Epiphora [3] which causes social embarrassment due to chronic watering from the eye [4]. Naso-lacrimal duct obstruction interferes with the normal flow of tears which leads to stasis. The accumulation of tears, mucoid secretions and desquamated cells provides a suitable medium for bacteriological growth in the lacrimal sac and eventually colonization by bacteria. It leads to infection and inflammation of the sac causing "Dacryocystitis". Chronic dacryocystitis is a constant threat to adjacent ocular surface soft tissue and act as a

Manuscript received: $10^{\text {th }}$ April 2018

Reviewed: $20^{\text {th }}$ April 2018

Author Corrected: $26^{\text {th }}$ April 2018

Accepted for Publication: $30^{\text {th }}$ April 2018 constant source of infection for corneal ulcer leading to severe complications. It can also lead to orbital cellulitis, cavernous sinus thrombosis and can endanger patient's life. There has been changing trends in the microbiological spectrum of dacryocystitis [5-9]. Geographical variation in the bacterial agents of dacryocystitis has been noted [10] along with difference in spectrum of chronic and acute dacryosystitis [2]. The knowledge of bacteriology of dacryocystitis would contribute to the choice of effective antimicrobial agents and would help to reduce the unnecessary load of antimicrobial agents and development of drug resistance [11-13]. Understanding the antibiogram for microorganism causing inflammation of lacrimal sac can be useful in choosing the best antimicrobial which in turn may result in prompt improvement while decreasing the risk of secondary ocular infection. Hence the present 


\section{Original Research Article}

study was conducted to evaluate theclinical profile and antibiogram of acute and chronic dacryocystitis.

\section{Material and Methods}

Type of study: A prospective observational study.

Duration and place of study: This study was conducted in the Department of Ophthalmology and Department of Microbiology, at a tertiary care center in northern India from January 2016 to June 2017. Ethical clearance was obtained prior to initiation of study from the Institutional ethics committee.

Inclusion and exclusion criteria: All patients attending outpatient ophthalmic department with acute or chronic dacryocystitis were included in the study after informed consent. Chronic dacryocystitis was defined as history of watering and/or discharge from the eye presenting over a long period with blockage in the lacrimal passage as evidenced by regurgitation test and syringing. Acute dacryocystitis was defined as pain, redness, and swelling in the lacrimal sac area.Patients who fulfilled above criteria were enrolled in study after informed consent. Patients with history of previous sac surgery, antibiotic therapy, diabetic patients under 10 years of age, and those not consenting for study were excluded from the study.
Sample collection: After clinical diagnosis of dacryocystitis was made, specimens (spontaneous discharge, discharge taken after application of pressure over lacrimal sac area, discharge following spontaneous bursting of abscess, discharge while syringing, following incision and drainage, surgically excised lacrimal sacs collected during dacryocy storhinostomy) were collected under strict aseptic precautions and were transferred to microbiological lab for gram staining, culture and sensitivity testing.

Processing of specimen collected: The collected sample were inoculated on blood agar, nutrient agar and mac-conkey agar with the help of an inoculation loop and were incubated at $37^{\circ} \mathrm{C}$ for $24-48$ hours.

Any growth on the plates was identified with standard microbiological techniques. The antibiotic susceptibility pattern was determined by standardized Kirby- Bauer disc diffusion method on a Muller- Hinton Agar (MHA).

Statistical methods: All the data was collected in the predesigned proforma. The data was crosschecked and entered in the Excel format. The descriptive analysis was done using the SPSS software version 16.

\section{Result}

Total 100 consecutive cases of dacryocystitis were enrolled in the study of which acute dacryocystitis was found in $23 \%$ of cases and chronic in $77 \%$ of cases. Thus, chronic dacryocystitis was nearly three times more common than acute dacryocystitis.

Table-1: Demographic profile of study patients (age, sex and socioeconomic class)

\begin{tabular}{|c|c|c|c|c|c|c|}
\hline & \multicolumn{2}{|c|}{ Acute $(\mathrm{N}=23)$} & \multicolumn{2}{|c|}{ Chronic $(\mathbf{N}=77)$} & \multicolumn{2}{|l|}{ Total } \\
\hline & No. of cases & $\%$ & No. of cases & $\%$ & No. of cases & $\%$ \\
\hline \multicolumn{7}{|l|}{ Age Group } \\
\hline $10-20$ & 0 & 0 & 0 & 0 & 0 & 0 \\
\hline$>20-30$ & 4 & 17.3 & 4 & 5.2 & 8 & 8 \\
\hline$>30-40$ & 6 & 26.2 & 13 & 16.9 & 19 & 19 \\
\hline$>40-50$ & 6 & 26.2 & 25 & 32.5 & 31 & 31 \\
\hline$>50-60$ & 5 & 21.7 & 19 & 24.7 & 24 & 24 \\
\hline$>60$ & 2 & 8.6 & 16 & 20.7 & 18 & 18 \\
\hline \multicolumn{7}{|l|}{ Sex } \\
\hline Females & 15 & 65.2 & 53 & 68.9 & 68 & 68 \\
\hline Males & 8 & 34.8 & 24 & 31.1 & 32 & 32 \\
\hline \multicolumn{7}{|c|}{ Socio economic class } \\
\hline Upper & 0 & 0 & 1 & 1.29 & 1 & 1 \\
\hline Upper middle & 2 & 8.69 & 5 & 6.49 & 7 & 7 \\
\hline Middle & 4 & 17.4 & 14 & 18.3 & 18 & 18 \\
\hline Lower middle & 1 & 4.3 & 16 & 20.4 & 17 & 17 \\
\hline Lower & 16 & 69.56 & 41 & 53.25 & 57 & 57 \\
\hline
\end{tabular}




\section{Original Research Article}

Table 1 show that maximum number of cases were observed in age group of 30-60 years (Middle age group) Acute dacryocystitis is more common in age group of 30-50 years (52.4\%) while chronic is more common in 40-60 (57.2\%) years. The average age of affection in acute dacryocystitis is around 43 years while it is 46 for chronic dacryocystitis. Males were affected in $32 \%$ of cases and females in $68 \%$ of cases.

Thus, females are affected nearly two times more commonly than males. Sex ratio (female: male) in acute dacryocystitis is 1.9 while it is 2.2 in chronic dacryocystitis. Most of patients belong to lower socio-economic status (nearly $74 \%$ ) in both acute and chronic dacryocystitis and only 1 case of chronic dacryocystitis and no case of acute dacryocystitis was seen in upper socio-economic status.

Table 2 shows that the involvement of left eye is more than the involvement of right eye (1.3 times). The main presenting symptom in acute dacryocystitis is pain, swelling and tenderness (in 100\% of cases) followed by watering (52.17\%) and discharge (13.04\%) and the main presenting symptom in chronic dacryocystitis is watering (in $100 \%$ of cases) followed by discharge (44\%) and swelling (14.28\%). Pain and tenderness are absent in chronic dacryocystitis. Red eye is most commonly associated both in acute and chronic dacryocystitis. Lid swelling is commonly found to be associated with acute and red eye with chronic dacryocystitis.

Table-2: Clinical profile of cases of dacryocystitis.

\begin{tabular}{|c|c|c|c|c|c|c|}
\hline \multirow{2}{*}{ Eye } & \multicolumn{2}{|c|}{ Acute (23) } & \multicolumn{2}{|c|}{ Chronic (77) } & \multicolumn{2}{|c|}{ Total } \\
\hline & No. of cases & $\%$ & No. of cases & $\%$ & No. of cases & $\%$ \\
\hline Right eye & 9 & $39.13 \%$ & 35 & $45.45 \%$ & 44 & $44 \%$ \\
\hline Left eye & 14 & $60.87 \%$ & 42 & $54.54 \%$ & 56 & $56 \%$ \\
\hline \multicolumn{7}{|l|}{ Symptoms } \\
\hline Watering & 12 & 52.17 & 77 & 100 & 89 & 89 \\
\hline Discharge & 3 & 13.04 & 44 & 57.14 & 47 & 47 \\
\hline Swelling & 23 & 100 & 11 & 14.28 & 34 & 34 \\
\hline Pain & 23 & 100 & 0 & 0 & 23 & 23 \\
\hline Tenderness & 23 & 100 & 0 & 0 & 23 & 23 \\
\hline \multicolumn{7}{|l|}{ Associated findings } \\
\hline Fistula & 0 & 0 & 4 & $5.2 \%$ & 4 & $4 \%$ \\
\hline Red eye & 5 & $21.7 \%$ & 7 & $9.1 \%$ & 12 & $12 \%$ \\
\hline Endopthalmitis & 0 & 0 & 1 & $1.2 \%$ & 1 & $1 \%$ \\
\hline Corneal ulcer & 0 & 0 & 4 & $5.2 \%$ & 4 & $4 \%$ \\
\hline Photophobia & 0 & 0 & 3 & $3.8 \%$ & 3 & $3 \%$ \\
\hline Headache & 1 & $4.3 \%$ & 2 & $2.6 \%$ & 3 & $3 \%$ \\
\hline Lid swelling & 4 & $17.3 \%$ & 0 & 0 & 4 & $4 \%$ \\
\hline Blephritis & 1 & $4.3 \%$ & 4 & $5.2 \%$ & 5 & $5 \%$ \\
\hline Cellulitis & 1 & $4.3 \%$ & 0 & 0 & 1 & $1 \%$ \\
\hline
\end{tabular}

Table 3 shows that the organisms are grown more in samples collected from chronic dacryocystitis $(72.72 \%)$ rather than acute dacryocystitis $(47.83 \%)$.

Table-3: Bacteriological examination of sac content in dacryocystitis.

\begin{tabular}{|c|c|c|c|c|}
\hline \multirow{2}{*}{$\begin{array}{c}\text { Culture Report Of } \\
\text { Sample }\end{array}$} & \multicolumn{3}{|c|}{ Type Of Dacryocystitis } \\
\cline { 2 - 5 } & No. of cases & $\%$ & No. of cases & $\%$ \\
\hline Positive & 11 & 47.83 & 56 & 72.72 \\
\hline Negative & 12 & 52.17 & 21 & 27.27 \\
\hline
\end{tabular}


Original Research Article

Table 4 shows that the Gram positive are predominant organisms $(72.86 \%)$ in both acute and chronic dacryocystitis in comparison to Gram negative organisms (27.14\%). Among the Gram-positive organisms, Staph. aureus (37.14\%) is the predominating organism while Pseudomonas $(20 \%)$ predominates amongGram negative organisms in both acute and chronic dacryocystitis.

Table-4: bacteriological examination of sac content in dacryocystitis

\begin{tabular}{|c|c|c|c|c|c|c|}
\hline \multirow{3}{*}{ Type Of Bacteria } & \multicolumn{6}{|c|}{ Organisms grown } \\
\hline & \multicolumn{2}{|c|}{ Acute (23) } & \multicolumn{2}{|c|}{ Chronic (77) } & \multicolumn{2}{|c|}{ Total (100) } \\
\hline & No. of Cases & $\%$ & No. of cases & $\%$ & No. of cases & $\%$ \\
\hline Gram positive & 9 & 39.1 & 42 & 54.54 & 51 & 72.86 \\
\hline S. Aureus & 5 & 21.7 & 21 & 27.3 & 26 & 37.14 \\
\hline S.epidermidis & 2 & 8.6 & 7 & 9.09 & 9 & 12.86 \\
\hline S.pneumoniae & 2 & 8.6 & 11 & 14.3 & 13 & 18.57 \\
\hline S. Pyogens & - & - & 2 & 2.5 & 2 & 2.85 \\
\hline S. Viridans & - & - & 1 & 1.3 & 1 & 1.42 \\
\hline Gram negative & 2 & 8.6 & 17 & 22.07 & 19 & 27.14 \\
\hline P. Aeruginosa & 2 & 8.6 & 12 & 15.6 & 14 & 20 \\
\hline Haemophillus & - & - & 1 & 1.3 & 1 & 1.42 \\
\hline Proteus & - & - & 2 & 2.5 & 2 & 2.85 \\
\hline Klebsiella & - & - & 2 & 2.5 & 2 & 2.85 \\
\hline
\end{tabular}

Table 5 shows that for gram positive bacteria, vancomycin is the most sensitive drug (98\%) followed by amikacin (78\%) followed by tobramycin and moxifloxacin (76\% each), ceftazidime (69\%), ceftraixone (67\%), gatifloxacin (67\%), ciprofloxacin $(65 \%)$ and gentamicin $(63 \%)$.

Table 5: Antibiotic sensitivity pattern among gram positive isolates.

\begin{tabular}{|c|c|c|c|c|c|c|c|c|c|}
\hline \multirow[b]{2}{*}{$\begin{array}{c}\text { Name of } \\
\text { the } \\
\text { bacterial } \\
\text { species } \\
\text { recovered }\end{array}$} & \multicolumn{9}{|c|}{ Number of patients sensitive to drug } \\
\hline & 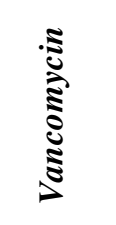 & & : & 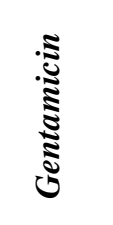 & 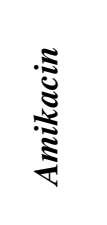 & 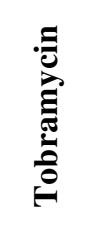 & 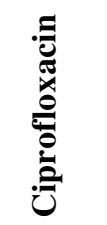 & 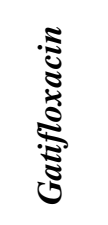 & 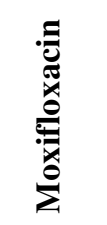 \\
\hline $\begin{array}{c}\text { S. Aureus } \\
(26)\end{array}$ & $\begin{array}{c}96.2 \% \\
(25)\end{array}$ & $\begin{array}{l}50 \% \\
(13)\end{array}$ & $\begin{array}{l}54 \% \\
(14)\end{array}$ & $\begin{array}{c}92.3 \% \\
(24)\end{array}$ & $\begin{array}{c}76.9 \% \\
(24)\end{array}$ & $\begin{array}{c}76.9 \% \\
(24)\end{array}$ & $\begin{array}{c}57.7 \% \\
(15)\end{array}$ & $\begin{array}{c}92.3 \% \\
(24)\end{array}$ & $\begin{array}{c}65.4 \% \\
(17)\end{array}$ \\
\hline $\begin{array}{l}\text { S.Epidermi } \\
\text { dis }(9)\end{array}$ & $\begin{array}{c}100 \% \\
(9)\end{array}$ & $\begin{array}{c}55.5 \% \\
(5)\end{array}$ & $\begin{array}{c}55.5 \% \\
(5)\end{array}$ & $\begin{array}{c}88.9 \% \\
(8)\end{array}$ & $\begin{array}{c}77.8 \% \\
(7)\end{array}$ & $\begin{array}{c}88.9 \% \\
\quad(8\end{array}$ & $\begin{array}{c}66.6 \% \\
(6)\end{array}$ & $\begin{array}{c}88.9 \% \\
\quad(8\end{array}$ & $\begin{array}{c}77.8 \% \\
(7)\end{array}$ \\
\hline $\begin{array}{l}\text { S.Pneumon } \\
\text { iae (13) }\end{array}$ & $\begin{array}{c}100 \% \\
(13)\end{array}$ & $\begin{array}{c}100 \% \\
(13)\end{array}$ & $\begin{array}{c}100 \% \\
(13)\end{array}$ & $\begin{array}{c}0.0 \% \\
(0)\end{array}$ & $\begin{array}{c}92.3 \% \\
(12)\end{array}$ & $\begin{array}{c}92.3 \% \\
(8)\end{array}$ & $\begin{array}{c}61.5 \% \\
(9)\end{array}$ & $\begin{array}{c}0.0 \% \\
(0)\end{array}$ & $\begin{array}{c}92.3 \% \\
(12)\end{array}$ \\
\hline $\begin{array}{c}\text { Viridans } \\
\text { (1) }\end{array}$ & $\begin{array}{c}100 \% \\
(1)\end{array}$ & $\begin{array}{c}100 \% \\
(1)\end{array}$ & $\begin{array}{c}100 \% \\
(1)\end{array}$ & $\begin{array}{c}0.0 \% \\
(0)\end{array}$ & $\begin{array}{c}100 \% \\
(1)\end{array}$ & $\begin{array}{c}100 \% \\
(1)\end{array}$ & $\begin{array}{c}100 \% \\
(1)\end{array}$ & $\begin{array}{c}0.0 \% \\
(0)\end{array}$ & $\begin{array}{c}100 \% \\
(1)\end{array}$ \\
\hline $\begin{array}{l}\text { Pyogenes } \\
\text { (2) }\end{array}$ & $\begin{array}{c}100 \% \\
(2)\end{array}$ & $\begin{array}{c}100 \% \\
(2)\end{array}$ & $\begin{array}{c}100 \% \\
(2)\end{array}$ & $\begin{array}{c}0.0 \% \\
(0)\end{array}$ & $\begin{array}{c}0.0 \% \\
(0)\end{array}$ & $\begin{array}{c}100 \% \\
(2)\end{array}$ & $\begin{array}{c}100 \% \\
(2)\end{array}$ & $\begin{array}{c}100 \% \\
(2)\end{array}$ & $\begin{array}{c}100 \% \\
(2)\end{array}$ \\
\hline Total (51) & $\begin{array}{l}98 \% \\
(50)\end{array}$ & $\begin{array}{l}67 \% \\
(34)\end{array}$ & $\begin{array}{r}69 \% \\
(35)\end{array}$ & $\begin{array}{l}63 \% \\
(32)\end{array}$ & $\begin{array}{l}78 \% \\
(40)\end{array}$ & $\begin{array}{l}76 \% \\
(39)\end{array}$ & $\begin{array}{l}65 \% \\
(33)\end{array}$ & $\begin{array}{l}67 \% \\
(34)\end{array}$ & $\begin{array}{l}76 \% \\
(39)\end{array}$ \\
\hline
\end{tabular}


Table-6: Antibiotic sensitivity pattern among gram negative isolates.

\begin{tabular}{|c|c|c|c|c|c|c|c|c|c|}
\hline \multirow[b]{2}{*}{$\begin{array}{c}\text { Name of } \\
\text { The } \\
\text { Bacterial } \\
\text { Species } \\
\text { Recovered }\end{array}$} & \multicolumn{9}{|c|}{ Patients sensitive to drug } \\
\hline & 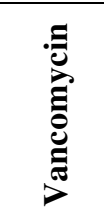 & $\frac{\sqrt{5}}{\stackrel{5}{5}}$ & U: & 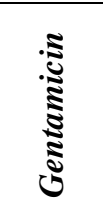 & 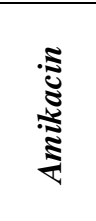 & 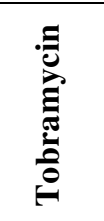 & 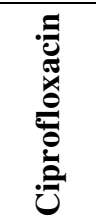 & 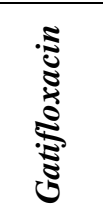 & 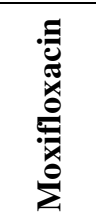 \\
\hline $\begin{array}{c}P . \\
\text { Aeruginosa } \\
(14)\end{array}$ & $\begin{array}{c}14.3 \% \\
(2)\end{array}$ & $\begin{array}{c}100 \% \\
(14)\end{array}$ & $\begin{array}{c}100 \% \\
(14)\end{array}$ & $\begin{array}{c}100 \% \\
(14)\end{array}$ & $\begin{array}{c}100 \% \\
(14)\end{array}$ & $\begin{array}{l}93 \% \\
(13)\end{array}$ & $\begin{array}{l}93 \% \\
(13)\end{array}$ & $\begin{array}{l}93 \% \\
(13)\end{array}$ & $\begin{array}{l}93 \% \\
(13)\end{array}$ \\
\hline $\begin{array}{c}\text { Klebsiella } \\
\text { (2) }\end{array}$ & $\begin{array}{c}0.0 \% \\
(0)\end{array}$ & $\begin{array}{c}100 \% \\
(2)\end{array}$ & $\begin{array}{c}100 \% \\
(2)\end{array}$ & $\begin{array}{c}100 \% \\
(2)\end{array}$ & $\begin{array}{c}100 \% \\
\text { (2) }\end{array}$ & $\begin{array}{c}100 \% \\
(2)\end{array}$ & $\begin{array}{c}100 \% \\
\text { (2) }\end{array}$ & $\begin{array}{c}100 \% \\
(2)\end{array}$ & $\begin{array}{c}100 \% \\
\text { (2) }\end{array}$ \\
\hline $\begin{array}{l}\text { Haemophill } \\
\text { us (1) }\end{array}$ & $\begin{array}{c}0.0 \% \\
(0)\end{array}$ & $\begin{array}{c}100 \% \\
(1)\end{array}$ & $\begin{array}{c}100 \% \\
(1)\end{array}$ & $\begin{array}{c}100 \% \\
(1)\end{array}$ & $\begin{array}{c}100 \% \\
(1)\end{array}$ & $\begin{array}{l}100 \% \\
(1)\end{array}$ & $\begin{array}{c}100 \% \\
(1)\end{array}$ & $\begin{array}{l}100 \% \\
(1)\end{array}$ & $\begin{array}{c}100 \% \\
(1)\end{array}$ \\
\hline Proteus (2) & $\begin{array}{c}0.0 \% \\
(0)\end{array}$ & $\begin{array}{c}100 \% \\
(2)\end{array}$ & $\begin{array}{c}100 \% \\
(2)\end{array}$ & $\begin{array}{c}100 \% \\
(2)\end{array}$ & $\begin{array}{c}100 \% \\
(2)\end{array}$ & $\begin{array}{c}100 \% \\
(2)\end{array}$ & $\begin{array}{c}100 \% \\
(2)\end{array}$ & $\begin{array}{c}100 \% \\
(2)\end{array}$ & $\begin{array}{c}100 \% \\
(2)\end{array}$ \\
\hline Total (19) & $\begin{array}{c}10 \% \\
(2)\end{array}$ & $\begin{array}{c}100 \% \\
(19)\end{array}$ & $\begin{array}{c}100 \% \\
(19)\end{array}$ & $\begin{array}{c}100 \% \\
(19)\end{array}$ & $\begin{array}{c}100 \% \\
(19)\end{array}$ & $\begin{array}{l}95 \% \\
(18)\end{array}$ & $\begin{array}{r}95 \% \\
(18)\end{array}$ & $\begin{array}{l}95 \% \\
(18)\end{array}$ & $\begin{array}{r}95 \% \\
(18)\end{array}$ \\
\hline
\end{tabular}

Table 6 shows that for gram negative bacteria, cephotaxime, ceftazidime, gentamycin and amikacin are 100\% sensitive. Tobramycin, ciprofloxacin and moxifloxacin are $95 \%$ sensitive. Vancomycin is having sensitivity of $10 \%$ only.

\section{Discussion}

Dacryocystitis or inflammation of lacrimal sac has been known to be a common disease of the eye worldwide. This study attempts to evaluate the changing trend in bacteriology and antibiotic sensitivity of dacryocystitis. In present study chronic dacryocystitiswas found to be more common than acute $(77 \%$ vs $23 \%)$ which is similar to the finding observed in different studies [1416]. However studies $[2,17,18]$ have reported different results, this difference can be due to the different geographical location, different sample size and difference in distribution of etiological factors.

In our study, dacryocystitis was found to be more common in middle age group (30-60yr) which is similar to other studies [19-23]. This age distribution could be attributed to a tendency of atony of the sac with age which in turn leads to stagnation of tears, resulting eventually in chronic irritation, inflammation and the decreased immune protection against microbial invasion.

In present study, females (68\%) were found to be more prone to develop dacryocystitis compared to males which is similar finding observed in other studies. [2,15,20,21,23] Females are more predisposed for dacryocystitis as bony nasolacrimal canal is narrower and flatter against the nasal floor in females than in males which may result incanalicular obstruction. As many patients come from lowersocial economic group, the disease could be linked to lower level of hygiene as was also seen in other studies [20,22-24]. In present study, watering was found to be the main symptom in chronic dacryocystitis while pain, swelling, tenderness were the main presenting symptoms in patients with acute dacryocystitis. Similar symptoms were reported in few other studies $[20,23,25,26]$ though their prevalence varied from study to study.

In present study, left eye was more commonly involved than righteye (1.27 times) similar to finding of studies $[25,27,28]$ which may be attributed to a greater angle formed between nasolacrimal duct and the lacrimal fossa on the right side than on the left side which in turn leads to predilection of the left side to get obstructed and infected.

Conjunctivitis was found frequently among patients with dacryocystitis $(12 \%)$. This may be attributed to building up of toxic debris on the surface of the eye, including the toxins produced by organisms normally inhabiting the ocular surface, which was unable to get cleared because of stasis of tear flow. Similar findings but with different prevalence were reported by few other studies $[20,23]$. In present study, organisms are 


\section{Original Research Article}

grown more in samples collected from chronic dacryocystitis $(72.72 \%$ of cases) rather than acute dacryocystitis $(47.83 \%$ of case). The Gram positive are predominant organisms $(72.86 \%)$ in comparison to Gram negative organisms (27.14\%).

Among theGram positive organisms, Staph aureus $(37.14 \%)$ is the predominating organism while Pseudomonas (20\%) predominates among Gram negative organisms. Similar observations were made by other studies [14, 20, 22, 28, 30, 31] though their prevalence varied from study to study.

In present study, we found that Vancomycin is highly active against all Gram positive organisms, while fluoro-quinolones and cephalosporins shown moderate sensitivity. However except Vancomycin all antibiotics (Tobramycin, gentamycin, amikacin, fluoroquinolones and cephalosporins) were found to be very active against gram negative bacteria.

These findings are congruent with the results quoted by other studies from India Prakash R et al, Mandal R et al, Ali MJ et al, Gupta $\mathrm{S}$ et al, Chandra TJ et al $[15,28$, $32,33,34]$.

Antibiotic misuse and/or overuse in the recent times is a cause of concern. Indiscriminate use of antibiotics leads to a varied antimicrobial sensitivity from community to community because of emergence of resistant strains which in turn cause changing trends of antibiotic susceptibility of micro-organism

\section{Conclusion}

The most common bacterial isolate in dacryocystitis, prevailing in this geographical area is Staphylococcus (Gram positive) followed by Pseudomonas, Pneumococcus and Staph. epidermidis. Antibiotic susceptibility of Gram positive bacteria is bestfor vancomycin and, that of Gram negative bacteria is for $3^{\text {rd }}$ generation cephalosporin, gentamycin and amikacin. Thus, the combination of two can be used as empirical therapy when the culture reports are awaited.

Contribution to the existing literature: The Present study has shown that bacterial isolation was more common in chronic dacryocystitis than in acute cases. Though gram positive organism were predominant organism but there was emergence of gram negative bacteria also Gram positive organism were sensitive to Vancomycin whereas gram negative isolates were also found to be sensitive to cephalosporin and fluoroquinolones.

Contribution of Authors

\begin{tabular}{|c|c|c|c|c|c|}
\hline & RG & PG & DKS & SV & AU \\
\hline Concepts & $\sqrt{ }$ & $\sqrt{ }$ & $\sqrt{ }$ & \\
\hline Design & & & $\sqrt{ }$ & & \\
\hline Definition of intellectual content & & & & $\sqrt{ }$ & \\
\hline Literature search & $\sqrt{ }$ & & & & \\
\hline Clinical studies & & & & $\sqrt{ }$ & $\sqrt{ }$ \\
\hline Experimental studies & & & & & \\
\hline Data acquisition & $\sqrt{ }$ & $\sqrt{ }$ & & \\
\hline Data analysis & $\sqrt{ }$ & $\sqrt{ }$ & & & $\sqrt{ }$ \\
\hline Statistical analysis & & $\sqrt{ }$ & & $\sqrt{ }$ & $\sqrt{ }$ \\
\hline Manuscript preparation & $\sqrt{ }$ & $\sqrt{ }$ & & & $\sqrt{ }$ \\
\hline Manuscript editing & $\sqrt{ }$ & $\sqrt{ }$ & $\sqrt{ }$ & & \\
\hline Manuscript review & & $\sqrt{ }$ & & & \\
\hline Guarantor & & & & & \\
\hline
\end{tabular}

Funding: Nil, Conflict of interest: None

Permission of IRB: Yes 


\section{References}

1. Disease of the Lacrimal Apparatus. In Parson;s Diseases of the Eye: Sihota R, Tandon R editors. Elsevier, New delhi. 2007; 20th Ed:pp 444-452.

2. Eshraghi B, Abdi P, Akbari M, Fard MA. Microbiologic spectrum of acute and chronic dacryocystitis. International journal of ophthalmology. 2014; 7 (5):864.

3. JACOBS HB. Symptomatic epiphora. $\mathrm{Br}$ J Ophthalmol. 1959 Jul;43:415-34.

4. Mandal R, Banerjee AR, Biswas MC, Mondal A, Kundu PK, Sasmal NK. Clinico bacteriological study of chronic dacryocystitis in adults. Journal of the Indian Medical Association. 2008 ;106(5):296-8.

5. Ali MJ, Joshi SD, Naik MN, Honavar SG. Clinical profile and management outcome of acute dacryocystitis: two decades of experience in a tertiary eye care center. Semin Ophthalmol. 2015 Mar; 30 (2): 118-23. doi: 10. 3109/08820538.2013. 833269. Epub 2013 Oct 30 .

6. Mills DM, Bodman MG, Meyer DR, Morton AD 3rd; ASOPRS Dacryocystitis Study Group. The microbiologic spectrum of dacryocystitis: a nationalstudy of acute versuschronic infection. Ophthalmic Plast Reconstr Surg.2007 Jul-Aug; 23 (4): 302-6.

7. Chaudhry IA, Shamsi FA, Al-RashedW. Bacteriology of chronic dacryocy stitisinatertiary eye care center. Ophthalmic Plast Reconstr Surg. 2005 May; 21 (3): 207-10

8. Huber-Spitzy V, Steinkogler FJ, Huber E, ArockerMettinger E, Schiffbänker M. Acquired dacryocystitis: microbiology and conservative therapy. Acta Ophthalmol (Copenh). 1992 Dec;70(6):745-9.

9. Sun $X$, Liang Q, Luo S, Wang Z, Li R, Jin X. Microbiological analysis of chronic dacryocystitis. Ophthalmic and Physiological Optics. 2005; 25 (3): 261-3.

10. Ramesh S, Ramakrishnan R, Bharathi MJ, Amuthan M, Viswanathan S. Prevalence of bacterial pathogens causingocular infections in South India. Indian J Pathol Microbiol. 2010 Apr-Jun; 53(2):281-6. doi: 10.4103/ 0377- 4929.64336.
11. Amin RM, Hussein FA, Idriss HF, Hanafy NF, Abdallah DM. Pathological, immuno histochemical and microbiologicalal analysis of lacrimal sac biopsies in patients with chronic dacrocystitis. International journal of ophthalmology. 2013;6(6):817-26.

12. Sharma S.Antibiotic resistance in ocular bacterial pathogens. Indian J Med Microbiol. 2011 Jul-Sep;29 (3): 218-22. doi: 10.4103/0255-0857.83903.

13. Modarrres SH, Lasheii A, Nassiri ON. Bacterial etiologic agents of ocular infection in children in the Islamic Republic of Iran. 1998;4(1):44-49.

14. Bharathi MJ, Ramakrishnan R, Maneksha V, Shivakumar C, Nithya V, Mittal S. Comparative bacteriology of acute and chronic dacryocystitis. Eye (Lond). 2008 Jul; 22(7):953-60. Epub 2007 Jun 29.

15. Prakash R., GirishBabu R.J., Nagaraj E.R., Prashanth H.V., Jayashree S. Shah. A bacteriological study of dacryocystitis. Journal Of Clinical And Diagnostic Research 2012 ; 6(4):652-655.

16. Rizvi SA, Rizvi M, Raut SD, Gupta Y, Maheshwari P. Etiology and antimicrobial sensitivity pattern in acute and chronic dacryocystitis. International Journal of Current Microbiology and Applied Sciences: ISSN: 2319-7706 Special Issue-1 (2015) pp. 269-280.

17. Shah CP, Santani D. A comparative bacteriological profile and antibiogram of dacryocystitis. Nepal J Ophthalmol. 2011 Jul-Dec;3(2):134-9.doi: http://dx.doi. org/10.3126/nepjoph.v3i2.5265.

18. Kandati J, Kumar GK, Avanish G, Buchineni M, Mohan R, Pathapati PS. Microbial surveillance of acute and chronic dacryocystitis in a tertiary care hospital. Journal of Evolution of Medical and Dental Sciences. 2015;4(3):408-16.

19. Diggle FH. Lacrymal Obstruction: Its Nasal Origin and Intranasal Treatment. Br Med J.1927 Nov 19;2 (3489):933-5

20. REDDY PS, REDDY B. Dacryocystitis; a clinicopathological study.J Indian Med Assoc.1955 Mar 1;24 (11):413-6.

21. Chaudhary M, Bhattarai A, Adhikari SK, Bhatta DR.Bacteriology and antimicrobialsusceptibility of 


\section{Original Research Article}

adultchronicdacryocystitis. Nepal J Ophthalmol. 2010 Jul-Dec;2(2):105-13.doi:10.3126/nepjoph.v2i2.3716

22. Sarkar I, Choudhury SK, Bandyopadhyay M, Sarkar K, Biswas J. A Clinicobacteriological Profile Of Chronic Dacryocystitis In Rural India. International journal of Health Science andResearch2015;5(7): 82-87.

23. Kalaivani K. Microbial Study Of Chronic Dacryocystitis In Adults. International Journal of Ocular Oncology and Oculoplasty. 2017;3(2):133-136.

24. Katre P, Harkare V. Epidemiological Study Of Dacryocystitis In Rural Population. Panacea Journal Of Medical Sciences. 2017 ;7(1):11-4.

25. Patel K, Magdum R, Sethia S, Lune A, Pradhan A, Misra RN. A Clinico-Bateriological Study Of Chronic Dacryocystitis. Sudanese Journal Of Ophthalmology. $2014 ; 6(1): 1-5$.

26. Sharat S, Nagaraja KS. A Study On The Epidemiology Of Chronic Dacryocystitis In An Economically-Deprived Population In South India. Journal of evolution of medical and dental sciencesjemds. 2016;5(70):5116-7.

27. Malik SR, Gupta AK, Chaterjee S, Bhardwaj OP, Saha M. Dacryocystography of normal and pathological lacrimal passages. Br J Ophthalmol. 1969 Mar; 53 (3): 174-9.

28. Mandal R, Banerjee AR, Biswas MC, Mondal A, Kundu PK, Sasmal NK. Clinico bacteriological Study Of Chronic Dacryocystitis In Adults. Journal Of the Indian Medical Association. 2008;106(5):296-8.
29. Kubravi SH, Qureshi ST, Akbar E, Nawaz S, Kawoosa K. Characteristics And Surgical Outcomes Of Patients Undergoing Dacryo cystorhinostomy In Kashmir. Journal of evolution of medical and dental sciences. 2016;5(93):6879-82.

30. Das JK, Deka AC, Kuri GC, Bhattacharjee K, Das $\mathrm{D}$, Gogoi K. Bacteriology of chronic dacryocystitis in adult population of northeast India. Orbit. 2008; 27 (4): 243-7. doi: $10 . \quad 1080 / 01676 \quad 83080 \quad 222$ 4668 .

31. Ahuja S, Chhabra AK, Agarwal J. Study Of Bacterial Spectrum In Patients Of Chronic Dacryocystitis, At A Tertiary Care Centre In Northern India. J Community Med Health Educ2017;7:536.doi: 10.4172 /2161-0711.1000536.

32. Ali MJ, Motukupally SR, Joshi SD, Naik MN. The microbiological profile of lacrimal abscess: two decades of experience from a tertiary eye care center. Journal of ophthalmic inflammation and infection. 2013;3(1): 57.doi: 10.1186/1869-5760-3-57.

33. Gupta S, Gupta S, Mahajan B. Bacteriology of Acquired DacryocystitisinA Tertiary Care Hospital of North India.JK Science Journal of Medical Science and Research 2014;16(3):110-113.

34. Chandra TJ, Satish K, Raj RS, Sharma YV. Isolation Of Dacrocystitis Causing Bacteria Among The Patients Of East Godavari District, Andhra Pradesh. Bangladesh Journal Of Medical Science. 2016;15(3): 399-402.

\section{How to cite this article?}

Garg R, Gupta P, Shakya D.K, Varandani S, Uchainiya A.Clinico-Microbiological profile in dacryocystitis: a prospective observational study. Int J Med Res Rev 2018;6 (04):210-217. doi:10.17511/ijmrr. 2018.i04.02. 